\title{
Morphological changes in the gills of Lophiosilurus alexandri exposed to un-ionized ammonia
}

\author{
E. L. Cardoso*, H. Chiarini-Garcia $\dagger$, R. M. A. Ferreira $\dagger$ and \\ C. R. POLIt \\ * Estação de Hidrobiologia e Piscicultura de Três Marias, CODEVASF, Caixa Postal \\ 11, 39205-000 Três Marias, MG; †Instituto de Ciências Biológicas, Universidade Federal \\ de Minas Gerais and \$Centro de Ciências Agrárias, Universidade Federal de Santa \\ Catarina, Brazil
}

(Received 18 August 1995, Accepted 28 February 1996)

\begin{abstract}
The average lethal concentration of un-ionized ammonia (48-h $\mathrm{LC}_{50} \mathrm{NH}_{3}$ ) has been determined by the static assay for larvae $\left(0.48 \mathrm{mg} \mathrm{l}^{-1}\right)$ and alevins $\left(0.92 \mathrm{mg} \mathrm{l}^{-1}\right)$ of ' pacamã' Lophiosilurus alexandri. Studies by light and scanning electron microscopes at the greatest concentration of $\mathrm{NH}_{3}\left(0.99 \mathrm{mg}^{-1}\right.$ for larvae and $1.5 \mathrm{mg} \mathrm{l}^{-1}$ for alevins) have shown that the changes in the cells and branchial tissue were more intense in the alevins.
\end{abstract}

(C) 1996 The Fisheries Society of the British Isles

Key words: Lophiosilurus alexandri; gills; un-ionized ammonia.

\section{INTRODUCTION}

The gills are the largest proportion of the outer surface area of fish and a few micrometers separate the blood from the water (Wood \& Soivio, 1991), which facilitates gaseous exchange, but allows the branchial tissue to be exposed to variations of the medium. Modifications in the concentration of $\mathrm{NaCl}$ (Perry \& Laurent, 1989) and of ammonia (Wajsbrot et al., 1993), in addition to variations of temperature (Boyd et al., 1980), pH (Wilkie \& Wood, 1994) and salinity (Avella et al., 1993), among other factors, induce morphological modifications or cellular adaptations, related to the plasticity of the branchial epithelium (Laurent \& Perry, 1990).

Ammonia is a common pollutant of natural aquatic systems and constitutes the main nitrogenous waste compound (Tomasso et al., 1980). It is produced mainly in the fish liver (Goldstein et al., 1982), reaches the gills through the blood (Evans \& More, 1988), and is excreted in the epithelium by a variety of means (Evans \& Cameron, 1986) and then it is transferred to the water. The accumulation of nitrogen may induce alterations in branchial tissue and cause fish mortality (Peters et al., 1984).

Lophiosilurus alexandri Steindachner, 1876, popularly known as ' pacamã' a neotropical siluriform, spawns naturally in ponds, is piscivorous and feeds on commercial fish food in its larval phase (Cardoso et al., 1988). The adults may reach up to $8 \mathrm{~kg}$ body weight (Sato, pers. comm.), and are considered a species with great potential for culture and for restocking hydroelectric reservoirs. 
A static bioassay has been developed in this study with the purpose of determining the average lethal concentration of un-ionized ammonia $\left(\mathrm{LC}_{50} \mathrm{NH}_{3}\right)$ and the histological and ultrastructural changes in the gills of pacamã larvae and alevins after exposure to the greatest concentration of $\mathrm{NH}_{3}$ tested in the bioassay.

\section{MATERIALS AND METHODS}

\section{FISH}

Larvae and alevins of L. alexandri, obtained from one natural spawning at the Estação de Hidrobiologia e Piscicultura de Três Marias-CODEVASF, were exposed to different levels of $\mathrm{NH}_{3}-\mathrm{N}$ during $48 \mathrm{~h}$ in order to determine the average lethal concentration of $\mathrm{NH}_{3}$ (48-h $\mathrm{LC}_{50} \mathrm{NH}_{3}$ ). The eggs were incubated and larvae and alevins raised in the laboratory. At beginning of the experiment, the 10-day-old larvae weighed on average $0 \cdot 02 \mathrm{~g}$ and the 35 -day-old alevins $0 \cdot 41 \pm 0 \cdot 11 \mathrm{~g}$.

\section{BIOASSAY AND EXPERIMENTAL PROTOCOL}

Static bioassays were modified according to APHA (1971) for each phase of pacamã development (larva and alevin). Ammonia was generated by diluting a solution of ammonium chloride $\left(\mathrm{NH}_{4} \mathrm{Cl}\right)$ in water. Five different concentrations of $\mathrm{NH}_{3}-\mathrm{N}$ and one control (water with no ammonia chloride) were tested three times each in 18 aquaria of 201 , each one containing 10 fishes of the same age group (Table I). Water $\mathrm{pH}$ was adjusted previously with solutions of $1.0 \mathrm{~N} \mathrm{NaOH}$ and $1.0 \mathrm{~N} \mathrm{HCl}$ (Thurston et al., 1981b) checked four times a day. The water temperature remained between 26 and $27^{\circ} \mathrm{C}$ and the rate of dissolved oxygen (Winkler method) was kept above $5.6 \mathrm{ml} 1^{-1}(65.7 \%$ of saturation) with the help of an air pump. The electric conductivity was measured using a S/01 conductimeter and the alkalinity and $\mathrm{NH}_{3}-\mathrm{N}$ measured according to APHA (1971).

Fish were not fed during the experimental period. The concentrations of $\mathrm{NH}_{3}-\mathrm{N}$ were determined according to the logarithmic graphic method (Reish \& Oshida, 1987) and according to Trussel (1972) the percentage of $\mathrm{NH}_{3}$ in the water was determined. The observations and removal of dead fish, according to APHA (1971) and Reish \& Oshida (1987) were done at the following intervals: $0 \cdot 5,1,2,4,6,8,10,12,24,48 \mathrm{~h}$.

\section{LIGHT AND ELECTRON MICROSCOPY ANALYSIS OF THE GILL}

Larvae and alevins gills of $L$. alexandri exposed to the greatest concentration of $\mathrm{NH}_{3}$ used in the bioassay, i.e. $0.99 \mathrm{mg}^{-1}$ and $1.5 \mathrm{mg} \mathrm{l}^{-1}$, respectively (Table I), were utilized for morphopathologic studies. Control fish were analysed for comparative purposes.

Gill fragments for light microscope analyses were fixed by immersion in 4\% paraformaldehyde in $0 \cdot 1 \mathrm{~m}$ buffer phosphate $(\mathrm{pH} 7 \cdot 2)$ for $24 \mathrm{~h}$ and embedded in glycol methacrylate (JB-4 Polysciences). The sections were stained with one of the following methods: haematoxylin-eosin (HE), toluidine blue-sodium borate, alcian blue 8GX (pH 1.0 and 2.5) and periodic acid-Schiff (PAS).

For ultrastructural study, the gills were fixed with $4 \%$ paraformaldehyde for $24 \mathrm{~h}$ and then in a modified solution of Karnovsky (Karnovsky, 1965) for $24 \mathrm{~h}$, being both fixatives as $4^{\circ} \mathrm{C}$. Postfixation was done with $2 \%$ osmium tetroxide in $0 \cdot 1 \mathrm{~m}$ buffer phosphate $\mathrm{pH} 7 \cdot 3$ for $2 \mathrm{~h}$. After immersion in $1 \%$ aqueous solution of tannic acid for $20 \mathrm{~min}$, the fragments were contrasted in aqueous solution of $1 \%$ osmium tetroxide for $2 \mathrm{~h}$. After dehydration, drying at critical point of $\mathrm{CO}_{2}$ and metallizing with gold, the fragments were examined in the Zeiss DSM 950 scanning electron microscope.

\section{STATISTICAL ANALYSES}

The physical and chemical data of water and the values of $\mathrm{LC}_{50}$ were submitted to the analysis of variance (ANOVA) and Tukey test. 


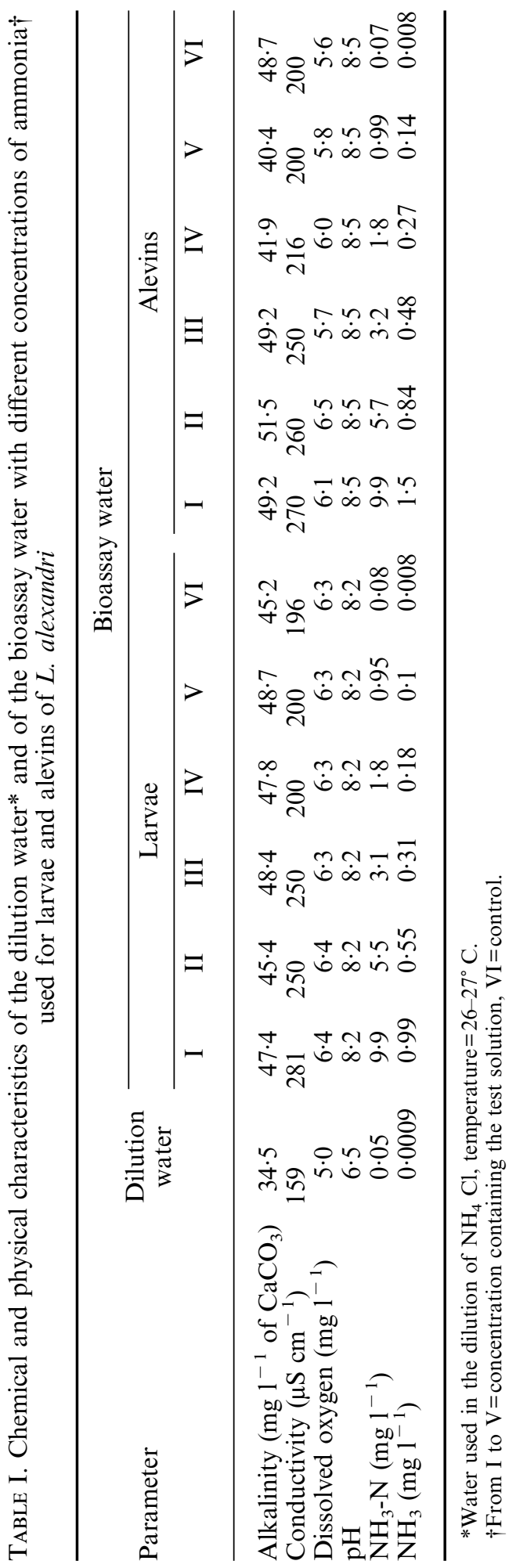




\section{RESULTS}

\section{CHEMICAL AND PHYSICAL CHARACTERISTICS OF THE WATER AND LC S $_{50}$}

There was no significant difference $(P<0 \cdot 05)$ in the values of dissolved oxygen, temperature, $\mathrm{pH}$ and alkalinity during the experiment. On the other hand, the conductivity varied significantly in bioassay water (Table I). The values found for $\mathrm{LC}_{50} \mathrm{NH}_{3}$, after $48 \mathrm{~h}$ exposure to un-ionized ammonia, were $0.48 \pm 0.0 \mathrm{mg}$ $1^{-1}$ for larvae and $0.92 \pm 0.07 \mathrm{mg}^{-1}$ for alevins. These variations were statistically significant $(P<0 \cdot 05)$.

\section{GILL MORPHOLOGY IN CONTROL FISH}

L. alexandri had four pairs of branchial arches, each containing two rows of well-developed and compactly organized primary filaments. Secondary lamellae were found on the lateral sides of the primary filaments [Figs 1(a-d), 2(a-d)]. The epithelium of both primary filaments and secondary lamellae was composed of pavement epithelial cells and three different types of glycoconjugate secreting cells: mucous pavement cells, mucous cells and globous cells. The secondary lamella exhibited chloride cells and pillar cells which delimit vascular channels where blood capillaries are found (Table II).

\section{GILL MORPHOLOGY IN FISH EXPOSED TO UN-IONIZED AMMONIA}

The morphologic changes were more evident in alevins and were not observed in the control fish. The main alterations observed in pacamã gills are shown in Table III and Figs 1(b), (d) and 2(b), (d), (f).

\section{DISCUSSION}

It is known that ammonia produces a toxic effect in temperate fishes (Tomasso et al., 1980; Thurston et al., 1984; Peters et al., 1984). In tropical fish species, with potential for aquaculture, studies on lethal concentration of ammonia in fish have been initiated (Ostrensky \& Brugger, 1992). According to Cardoso (1992), establishment of the toxic threshold of $\mathrm{NH}_{3}$ in intensive culture is fundamental to larval raising and pond growing. In fact, the accumulation of nitrogen and products of decomposition and the diurnal fluctuation in the concentration of dissolved gas, may induce small quantities of un-ionized ammonia sufficient to damage the branchial tissue (Peters et al., 1984).

\section{THE WATER AND $\mathrm{LC}_{50} \mathrm{NH}_{3}$}

The un-ionized form of ammonia may be toxic to fish depending on factors such as $\mathrm{pH}$ variation (Thurston et al., 1981a), reduction of the dissolved oxygen level (Thurston et al., 1981b) and alterations in water temperature (Wajsbrot et al., 1993). In the present work, the values of $\mathrm{pH}$, dissolved oxygen and temperature were maintained under control allowing the rate of $\mathrm{NH}_{3}$ in the water to remain in the concentrations and ranges previously established. Alkalinity did not present a significant variation whilst the electric conductivity presented significant differences. According to Esteves (1988), temperature, $\mathrm{pH}$, in addition to ionizable substances may contribute to the elevation of conductivity, although in our work temperature and $\mathrm{pH}$ were maintained constant. 

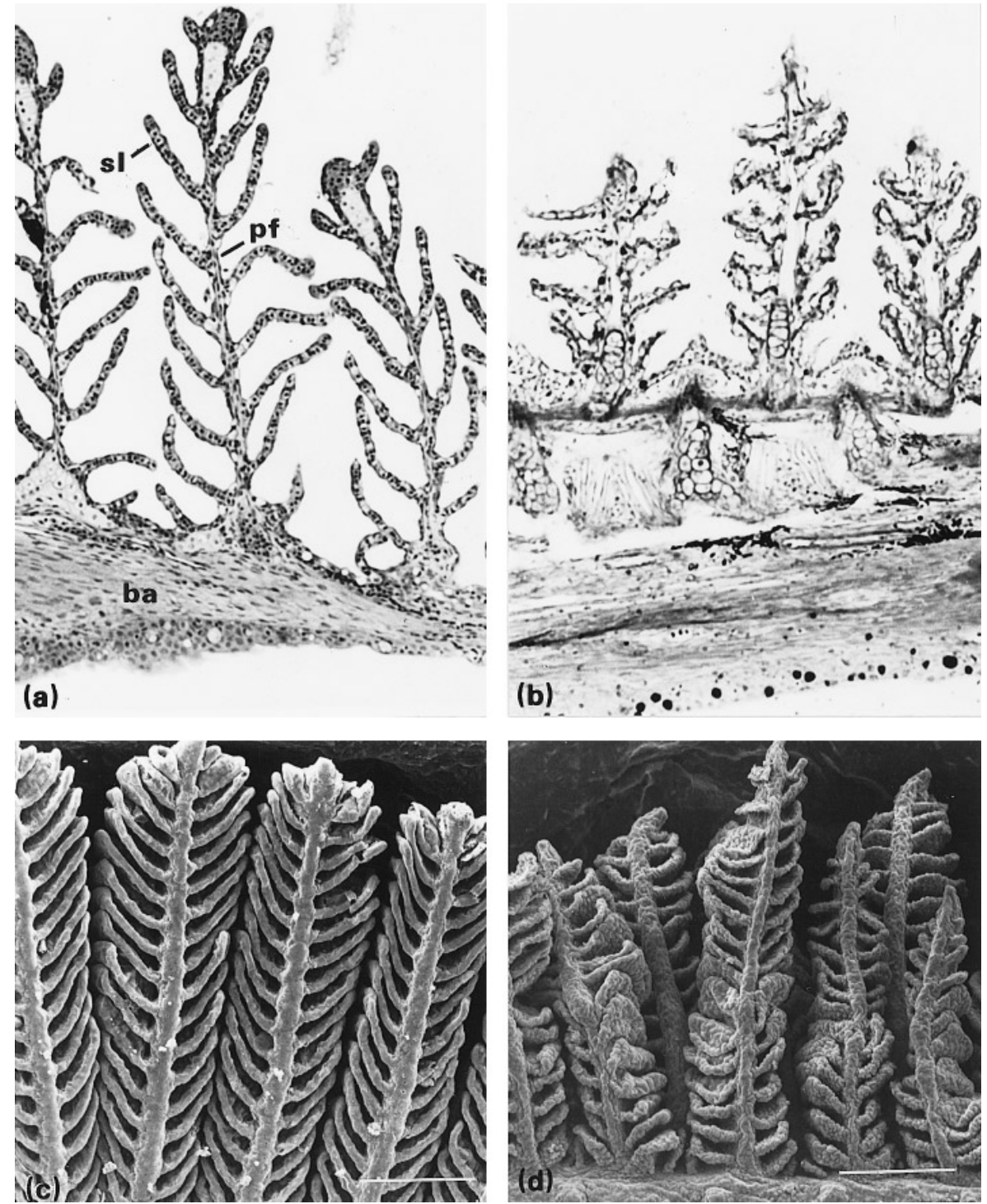

Fig. 1. Light (a, b) and scanning electron (c, d) micrograph of the gills of L. alexandri alevins. (a) In the gills of control fish branchial arch (ba), primary filament (pf) and secondary lamella (sl); haematoxylin-eosin. $\times 70$. (b) Notice the morphological changes which have occurred in the gills after the treatment with $1.5 \mathrm{mg}^{-1} \mathrm{NH}_{3}$. Tissue dissociation is seen in the central axis of the secondary lamella and the blood capillaries are swelled; Schiff-periodic acid. $\times 70$. (c) Gill of control fish seen in the SEM. $\times 140$; bar $100 \mu \mathrm{m}$. (d) The gills of the treated fish are seen to be disorganized due to the change in orientation of primary filaments and secondary lamellae. $\times 140$; bar $100 \mu \mathrm{m}$.

$\mathrm{LC}_{50} \mathrm{NH}_{3}$ varied significantly for larvae $\left(0 \cdot 48 \pm 0 \cdot 0 \mathrm{mg} \mathrm{1}^{-1}\right)$ and for alevins $\left(0.92 \pm 0.07 \mathrm{mg} \mathrm{1}^{-1}\right)$. Bioassays with different species, age and time of exposure to $\mathrm{NH}_{3}$, or the conjugation of ammonia with other substances in the medium have presented different $\mathrm{LC}_{50}$ (Soderberg et al., 1984; Thurston et al., 1986; Wilkie \& Wood, 1994). Conflicting results showing different levels of $\mathrm{NH}_{3}$ were 
probably due to the various test conditions used, constraining the value of such comparisons (Wajsbrot et al., 1993).

After $24 \mathrm{~h}$ of exposure to $0.99 \mathrm{mg} 1^{-1} \mathrm{NH}_{3}$, all of the larvae died, whilst the alevins survived for up to $12 \mathrm{~h}$ at $1.5 \mathrm{mg} 1^{-1} \mathrm{NH}_{3}$. The results suggest an inverse ratio between $\mathrm{NH}_{3}$ dosage and survival time of larvae and alevins. In fact, Colt
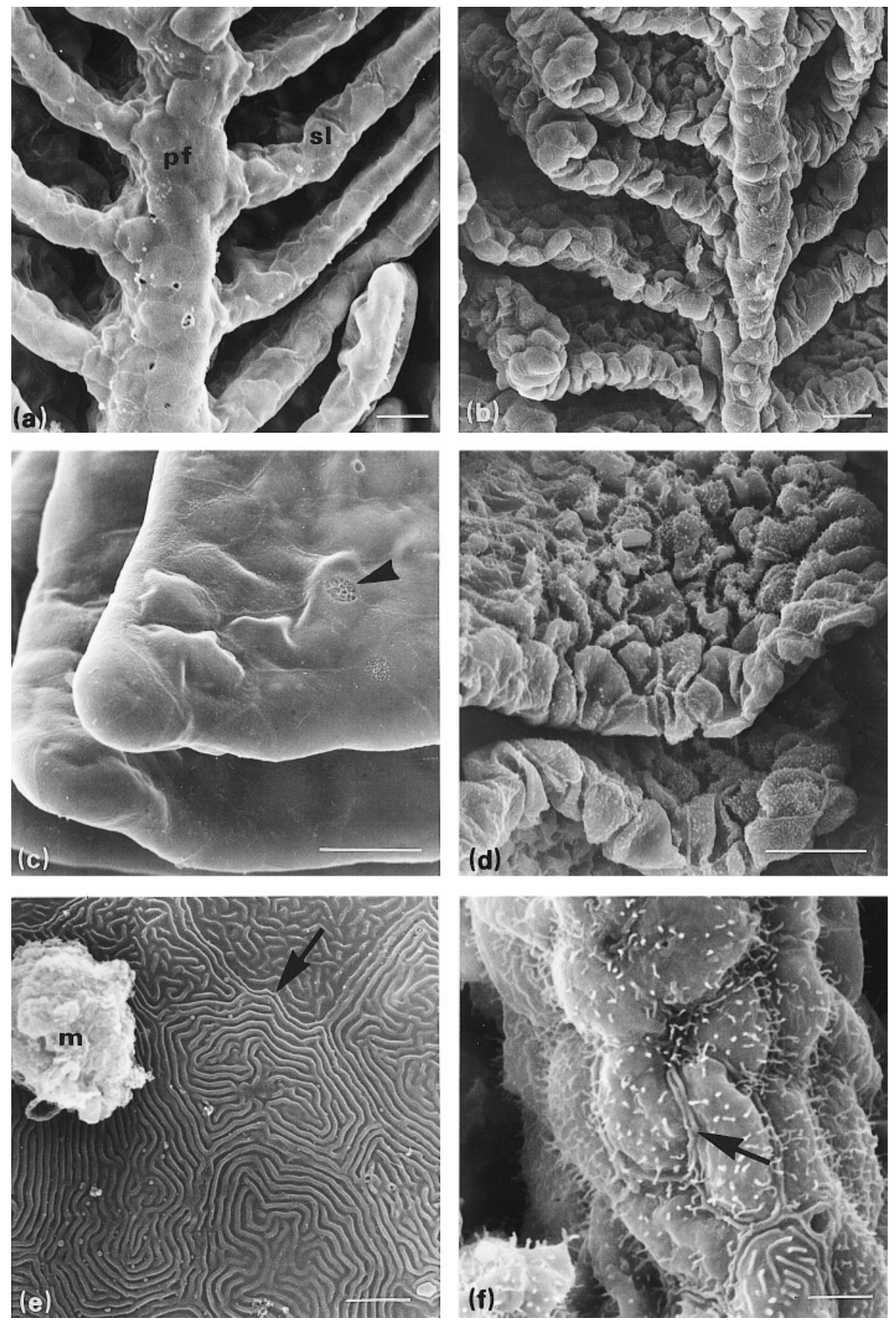
TABLE II. Histological and histochemical characteristics of the gill cells in L. alexandri

\begin{tabular}{|c|c|c|c|c|c|}
\hline \multirow{3}{*}{ Cell type } & \multicolumn{2}{|c|}{ Histological staining } & \multicolumn{3}{|c|}{ Histochemical reaction } \\
\hline & \multirow[t]{2}{*}{ Acidophilia } & \multirow[t]{2}{*}{ Metachromasia } & \multirow[t]{2}{*}{ PAS } & \multicolumn{2}{|c|}{ Alcian-blue $(\mathrm{pH})$} \\
\hline & & & & $1 \cdot 0$ & $2 \cdot 5$ \\
\hline Pavement epithelial & + & - & - & - & - \\
\hline Chloride & - & - & - & - & - \\
\hline Pillar & - & - & - & - & - \\
\hline \multicolumn{6}{|l|}{ Mucous cells: } \\
\hline Mucous pavement & + & - & + & - & - \\
\hline Mucous & + & + & ++ & +++ & ++ \\
\hline Globous & + & + & +++ & ++ & +++ \\
\hline
\end{tabular}

Staining and reaction intensity: $(-)$ negative; $(+)$ weak positive; $(++)$ moderately positive; $(+++)$ strong positive.

\& Tchobanoglous (1978) consider that sensitivity to ammonia varies with the fish's age and size.

\section{MORPHOPATHOLOGICAL ANALYSIS}

The gills of $L$. alexandri larvae and alevins were injured by the un-ionized ammonia from the average lethal concentration $\left(\mathrm{LC}_{50}\right)$ up to the most elevated level tested in the bioassay. The histologic changes observed were dissociation of the epithelium of the primary filaments and secondary lamellae, hypertrophy of the mucous pavement cells, increasing mucus secretion, and disorganization and rupture of the epithelium. These alterations have been seen also by Munshi \& Singh (1992) studying the effects of low pH on gills. Fusion of secondary lamellae and expanded blood space have also been seen in pacamã. Burkhalter \& Kaya (1977) observed epithelial hypertrophy in other species, Soderberg et al. (1984) found an oedema between the epithelium and blood capillaries, while Munshi \& Singh (1992) mentioned the occurrence of lamellar fusion.

Pavement cells acquired a globous form and a more evident cellular outline in L. alexandri. The microfolds presented intense evagination and depression of the plasma membrane in the cells present in the primary filament and secondary lamellae. Variations in the epithelial surface of gills show important physiological adaptations, related to the area available for increased gaseous exchanges (Kendall \& Dale, 1979) and support for the mucus cover (Hughes, 1979).

FIG. 2. Scanning electron micrograph (a-f) of gills of L. alexandri alevins. Gills of control fish (a, c, e) and after treatment with $1.5 \mathrm{mg} \mathrm{1^{-1 }}$ of $\mathrm{NH}_{3}$ (b, d, f). (a) Panoramic micrograph of primary filament (pf) and secondary lamella (sl). $\times 70$; bar $100 \mu \mathrm{m}$. (b) The retraction of surface cells and folds in the distal extremity of secondary lamellae in the gill of fish treated with ammonia is observed. $\times 70$; bar $100 \mu \mathrm{m}$. (c) Note the flat surface of the pavement epithelial cell of the secondary lamella in un-treated fish; chloride cell (arrow head). $\times 1400$; bar $10 \mu \mathrm{m}$. (d) After treatment with ammonia pavement epithelial cell of the secondary lamella is observed in the globous form. $\times 1400$; bar $10 \mu \mathrm{m}$. (e) Observe that in the primary filament of the control fish the microfolds on the surface of the pavement epithelial cells are organized in a finger-print form and the cellular limits are visualized (arrow). A great mucus accumulation (m) is seen in the branchial surface. $\times 4200$; bar $2 \mu \mathrm{m}$. (f) Otherwise, the primary filaments of the microfolds in the treated animals acquire a filiform aspect and the cellular limits are more evident (arrow). $\times 4200$; bar $2 \mu \mathrm{m}$. 
TABLE III. Gill lesions in larvae and alevins of $L$. alexandri exposed to the highest $\mathrm{NH}_{3}$ concentration

\begin{tabular}{lll}
\hline Fish & Method & \multicolumn{1}{c}{ Gill lesions } \\
\hline LM* & $\begin{array}{l}\text { Disorganization of the branchial tissue } \\
\text { Cellular necrosis } \\
\text { Hypertrophy of the mucous pavement cell } \\
\text { Dissociation and rupture of the branchial epithelia } \\
\text { Fusion of the secondary lamellae } \\
\text { Swelling of the capillaries (secondary lamellae) } \\
\text { Dissociation between the epithelium and the pillar cells } \\
\text { Pronounced convoluted microfolds } \\
\text { Outline of the pavement epithelial cell evident } \\
\text { Folds in distal edge of the secondary lamellae } \\
\text { Increased mucus production }\end{array}$ \\
&
\end{tabular}

*Light microscopy.

**Scanning electron microscope.

In the present study, a thick mucus layer has replaced the globules and the flocculant mass seen in the control fish, while Powell et al. (1992) observed the mucous lamina to be different from the glycocalyx layer. The mucus production in the gills is related to high water flow (Morgan \& Tovell, 1973) and to protection against the abrasive action of particles in suspension (Lewis, 1979). The pores of mucous cells in L. alexandri gills were apparently greater in diameter, suggesting an increased secretion rate. It is known that the stress caused by variations in the environment and pathologic agents induce the proliferation of mucous cells (Perry \& Laurent, 1989) and the increase of secretion (Wipfli et al., 1994).

The distal extremity of secondary lamellae of pacamã were bent, with a reduction of the interlamellar space, which was also seen by Roy et al. (1986).

Chloride cells, which have several functions in freshwater fish, have a role in the absorption of $\mathrm{Ca}^{2+}, \mathrm{NaCl}$ and acid-base control (Laurent \& Perry, 1991). In pacamã, the identification of these cells by light microscope was difficult since their cytoplasm was not stained. On the other hand, morphological changes were not observed in chloride cells of $L$. alexandri at the ultrastructural level.

We conclude that concentrations above $0.48 \mathrm{mg} \mathrm{l}^{-1}$ of $\mathrm{NH}_{3}$, responsible for the mortality of $50 \%$ of the fish, limit the cultivation of pacamã in the initial phases of life, compromising the success of its production. Mortality in the present study was probably caused by alterations in the gills morphology and physiology.

We thank G. D. Cassali for guidance in histopathological analysis and the late J. C. Amorim for guidance in water physical-chemical analyses. This work has been supported in part by PRPq-UFMG.

\section{References}

APHA (American Public Health Association), American Water Works Association, and Water Pollution Control Federation. (1971). Standard Methods for the Examination of Water and Wastewater. 13th edn. New York: American Public Health Association. 
Avella, M., Berhaut, J. \& Bornancin, M. (1993). Salinity tolerance of two tropical fishes, Oreochromis aureus and $O$. niloticus. I. Biochemical and morphological changes in the gill epithelium. Journal of Fish Biology 42, 243-254.

Boyd, R. B., DeVries, A. L., Eastman, J. T. \& Pietra, G. G. (1980). The secondary lamellae of the gills of cold water (high latitude) Teleosts. Cell and Tissue Research 213, 361-367.

Burkhalter, D. E. \& Kaya, C. M. (1977). Effects of prolonged exposure to ammonia on fertilized eggs and sac fry of rainbow trout (Salmo gairdneri). Transactions of the American Fisheries Society 106, 470-475.

Cardoso, E. L., Hancz, C. \& Ferreira, R. M. A. (1988). Alimentação de pós-larvas e alevinos de trairão (Hoplias lacerdae Ribeiro, 1908) e pacamã (Lophiosilurus alexandri Steindachner, 1876) mantidos em laboratório. In AquiculturaAssociação Mineira de Aquicultura (Resumos dos Encontros 1982-1987). (CODEVASF, ed.), pp. 116-117. Brasília: Ministério da Irrigaçaõ.

Cardoso, E. L. (1992). Toxidez de amônia não ionizada e seu efeito sobre a pele e brânquias de Lophiosilirus alexandri Steindachner, 1876; Prochilodus affinis Reinhardt, 1874; Prochilodus marggravii (Walbaum, 1792); Leporinus elongatus Valenciennes, 1849 (Pisces, Teleostei). Md. Thesis, Universidade Federal de Santa Catarina. $122 \mathrm{p}$.

Colt, J. \& Tchobanoglous, G. (1978). Chronic exposure of channel catfish, Ictalurus punctatus, to ammonia: effects on growth and survival. Aquaculture 15, 353-372.

Esteves, F. A. (1988). Fundamentos de Limnologia. Rio de Janeiro: Interciências: Finep.

Evans, D. H. \& Cameron, J. N. (1986). Gill ammonia transport. Journal of Experimental Zoology 239, 17-23.

Evans, D. H. \& More, K. J. (1988). Modes of ammonia transport across the gill epithelium of the dogfish pup (Squalus acanthias). Journal of Experimental Biology 138, 375-397.

Goldstein, L., Claiborne, J. B. \& Evans, D. E. (1982). Ammonia excretion by the gills of two marine teleost fish: the importance of $\mathrm{NH}_{4}+$ permeance. The Journal of Experimental Zoology 219, 395-397.

Hughes, G. M. (1979). Scanning electron microscopy of the respiratory surfaces of trout gills. Journal of Zoology (London) 187, 443-453.

Karnovsky, M. J. A. (1965). A formaldehyde-glutaraldehyde fixative of high osmolality for use in electron microscopy. Journal of Cell Biology 27, 137-138.

Kendall, M. W. \& Dale, J. E. (1979). Scanning and transmission electron microscopic observations of rainbow trout (Salmo gairdneri) gill. Journal of the Fisheries Research Board Canada 36, 1072-1079.

Laurent, P. \& Perry, S. F. (1990). Effects of cortisol on gill chloride cell morphology and ionic uptake in the freshwater trout, Salmo gairdneri. Cell and Tissue Research 259, 429-442.

Laurent, P. \& Perry, S. F. (1991). Environmental effects on fish gill morphology. Physiological Zoology 64, 4-25.

Lewis, S. V. (1979). A scanning electron microscope study of the gills of the air-breathing catfish, Clarias batrachus L. Journal of Fish Biology 15, 381-384.

Morgan, M. \& Tovell, P. W. A. (1973). The structure of the gill of the trout, Salmo gairdneri (Richardson). Zeitschrift für Zellforschung und Mikroskopische Anatomie 142, 147-162.

Munshi, J. S. D. \& Singh, A. (1992). Scanning electron microscopic evaluation of effects of low pH on gill of Channa punctata (Bloch). Journal of Fish Biology 41, 83-89.

Ostrensky, A. \& Brugger, A. (1992). Studies on the viability of silverside Odontesthes argentinensis cultivations: acute toxicity of ammonia. Ciências e Cultura 44, $413-414$.

Perry, S. F. \& Laurent, P. (1989). Adaptational response of rainbow trout to lowered external $\mathrm{NaCl}$ concentration: contribution of the branchial chloride cell. Journal of Experimental Biology 147, 147-168.

Peters, G., Hoffmann, R. \& Klinger, H. (1984). Environment-induced gill disease of cultured rainbow trout (Salmo gairdneri). Aquaculture 38, 105-126. 
Powell, M. D., Speare, D. J. \& Burka, J. F. (1992). Fixation of mucus on rainbow trout (Oncorhynchus mykiss Walbaum) gills for light and electron microscopy. Journal of Fish Biology 41, 813-824.

Reish, D. L. \& Oshida, P. S. (1987). Manual of methods in aquatic environment research, part. 10. Short-term static bioassay. Rome: FAO. Fisheries Technical Paper. 62p.

Roy, P. K., Munshi, J. S. D. \& Munshi, J. D. (1986). Scanning electron microscopic evaluation of effects of saponin on gills of the climbing perch, Anabas testudineus (Bloch) (Anabantidae: Pisces). Indian Journal of Experimental Biology 24, 511516.

Soderberg, R. W., McGee, M. V., Grizzle, J. M. \& Boyd, C. E. (1984). Comparative histology of rainbow trout and channel catfish grown in intensive static water aquaculture. The Progressive Fish-Culturist 46, 195-199.

Thurston, R. V., Russo, R. C. \& Vinogradov, G. A. (1981a). Ammonia toxicity to fishes. Effects of $\mathrm{pH}$ on the toxicity of the un-ionized ammonia species. Environmental Science and Technology 15, 7-12.

Thurston, R. V., Phillips, G. R. \& Russo, R. C. (1981b). Increased toxicity of ammonia to rainbow trout (Salmo gairdneri) resulting from reduced concentrations of dissolved oxygen. Canadian Journal of Fisheries and Aquatic Sciences 38, 983-988.

Thurston, R. V., Russo, R. C., Luedtke, R. J., Smith, C. E., Meyn, E. L., Chakoumakos, C., Wang, K. C. \& Brown, C. J. D. (1984). Chronic toxicity of ammonia to rainbow trout. Transactions of the American Fisheries Society 113, 56-73.

Thurston, R. V., Russo, R. C., Meyn, E. L., Zajdel, R. K. \& Smith, C. E. (1986). Chronic toxicity of ammonia to fathead minnows. Transactions of the American Fisheries Society 115, 196-207.

Tomasso, J. R., Goudie, C. A., Simco, B. A. \& Davis, K. B. (1980). Effects of environmental $\mathrm{pH}$ and calcium on ammonia toxicity in channel catfish. Transactions of the American Fisheries Society 109, 229-234.

Trussel, R. P. (1972). The percent un-ionized ammonia in aqueous ammonia solution at different $\mathrm{pH}$ levels and temperature. Journal of the Fisheries Research Board Canada 29, 1505-1507.

Wajsbrot, N., Gasith, A., Diamant, A. \& Popper, D. M. (1993). Chronic toxicity of ammonia to juvenile gilthead seabream Sparus aurata and related histopathological effects. Journal of Fish Biology 42, 321-328.

Wilkie, M. P. \& Wood, C. M. (1994). The effects of extremely alkaline water (pH 9.5) on rainbow trout gill function and morphology. Journal of Fish Biology 45, 87-98.

Wipfli, M. S., Merritt, R. W. \& Taylor, W. W. (1994). Low toxicity of the black fly larvicide Bacillus thuringiensis var. israelensis to early stages of brook trout (Salvelinus fontinalis) brown trout (Salmo trutta), and steelhead trout (Oncorhynchus mykiss) following direct and indirect exposure. Canadian Journal of Fisheries and Aquatic Sciences 51, 1451-1458.

Wood, C. M. \& Soivio, A. (1991). Environmental effects on gill function: an introduction. Physiological Zoology 64, 1-3. 